August 2001 • NREL/CP-540-31085

\title{
Test Results and Modeling of the Honda Insight Using ADVISOR
}

\section{Preprint}

K.J. Kelly and M. Zolot

National Renewable Energy Laboratory

G. Glinsky and A. Hieronymus

Environmental Testing Corporation

To be presented at the SAE Future Transportation Technologies Conference, Costa Mesa, CA

August 20 - 22, 2001

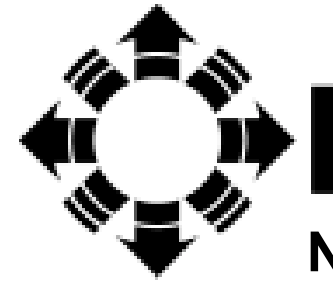

\section{NPEI}

National Renewable Energy Laboratory

1617 Cole Boulevard

Golden, Colorado 80401-3393

NREL is a U.S. Department of Energy Laboratory

Operated by Midwest Research Institute $\bullet$ Battelle $\bullet$ Bechtel

Contract No. DE-AC36-99-G010337 


\section{NOTICE}

The submitted manuscript has been offered by an employee of the Midwest Research Institute (MRI), a contractor of the US Government under Contract No. DE-AC36-99G010337. Accordingly, the US Government and MRI retain a nonexclusive royalty-free license to publish or reproduce the published form of this contribution, or allow others to do so, for US Government purposes.

This report was prepared as an account of work sponsored by an agency of the United States government. Neither the United States government nor any agency thereof, nor any of their employees, makes any warranty, express or implied, or assumes any legal liability or responsibility for the accuracy, completeness, or usefulness of any information, apparatus, product, or process disclosed, or represents that its use would not infringe privately owned rights. Reference herein to any specific commercial product, process, or service by trade name, trademark, manufacturer, or otherwise does not necessarily constitute or imply its endorsement, recommendation, or favoring by the United States government or any agency thereof. The views and opinions of authors expressed herein do not necessarily state or reflect those of the United States government or any agency thereof.

Available electronically at http://www.osti.gov/bridge

Available for a processing fee to U.S. Department of Energy and its contractors, in paper, from:

U.S. Department of Energy

Office of Scientific and Technical Information

P.O. Box 62

Oak Ridge, TN 37831-0062

phone: 865.576 .8401

fax: 865.576.5728

email: reports@adonis.osti.gov

Available for sale to the public, in paper, from:

U.S. Department of Commerce

National Technical Information Service

5285 Port Royal Road

Springfield, VA 22161

phone: 800.553 .6847

fax:703.605.6900

email: orders@ntis.fedworld.gov

online ordering: http://www.ntis.gov/ordering.htm

Printed on paper containing at least $50 \%$ wastepaper, including $20 \%$ postconsumer waste 


\title{
Test Results and Modeling of the Honda Insight using ADVISOR
}

\author{
Kenneth J. Kelly, Matthew Zolot \\ National Renewable Energy Laboratory \\ Gerard Glinsky, Arthur Hieronymus \\ Environmental Testing Corporation
}

\begin{abstract}
The National Renewable Energy Laboratory (NREL) has conducted a series of chassis dynamometer and road tests on the 2000 model-year Honda Insight. This paper will focus on results from the testing, how the results have been applied to NREL's Advanced Vehicle Simulator (ADVISOR), and how test results compare to the model predictions and published data. The chassis dynamometer testing included the FTP-75 emissions certification test procedure, highway fuel economy test, US06 aggressive driving cycle conducted at $0^{\circ} \mathrm{C}, 20^{\circ} \mathrm{C}$, and $40^{\circ} \mathrm{C}$, and the SC03 test performed at $35^{\circ} \mathrm{C}$ with the air conditioning on and with the air conditioning off. Data collection included bag and continuously sampled emissions (for the chassis tests), engine and vehicle operating parameters, battery cell temperatures and voltages, motor and auxiliary currents, and cabin temperatures. Test results are being used in three NREL program areas including: correlation and enhancement of the ADVISOR model; understanding battery performance under various conditions and the development of a temperature dependent battery pack model; and to determine the effect of air conditioning on fuel economy and emissions from highly efficient vehicles. Results from the testing have shown good agreement with predicted behavior and published data. Detailed test data have also yielded important insights into the vehicle control strategies and component performance that have been incorporated into ADVISOR.
\end{abstract}

\section{INTRODUCTION}

The National Renewable Energy Laboratory, with funding from the United States Department of Energy developed the Advanced Vehicle Simulator, better known as ADVISOR, for fast and accurate simulations of both conventional and advanced vehicle configurations.

ADVISOR was first developed in November 1994. Its main purpose was to help manage the Department of Energy's Hybrid Electric Vehicle (HEV) program subcontracts by facilitating an understanding of the technical challenges inherent in the design of highefficiency HEVs. Since that time, there have been three major upgrades leading to the release of ADVISOR 3.1 in February of 2001. Over 3000 users from over 70 countries have downloaded the program from the ADVISOR web site (http://www.ctts.nrel.gov/analysis/ advisor.html). Approximately $60 \%$ of those users are from private industry and $35 \%$ are from academia around the world.

The 2000 model-year Honda Insight was the first HEV available for sale in the United States. The year that it was released, it had the highest EPA fuel economy ratings (65 $\mathrm{mph}$ in the city and 70 on the highway) of any car sold in the U.S. The NREL HEV Program obtained a Honda Insight for the purpose of testing and validation of the ADVISOR model. Testing of the Insight is focussed at providing data and information for ADVISOR model development and validation, studying the effects of air conditioning $(\mathrm{A} / \mathrm{C})$ on fuel economy and emissions, and to contribute to the development of an improved vehicle battery model.

This paper will focus on test results from the Honda Insight and their application to the ADVISOR model. Testing of the Honda Insight provides detailed data that can be used to provide a benchmark of the ADVISOR model and to improve the model through a more detailed understanding of the vehicle behavior and control strategies under various test conditions.

\section{TEST VEHICLE AND INSTRUMENTATION}

TEST VEHICLE - The test vehicle was a 2000 model year Honda Insight. This is a two-passenger, parallel hybrid electric vehicle with a $1.0 \mathrm{~L}, 50 \mathrm{~kW}(67 \mathrm{hp})$ gasoline engine combined with a $10 \mathrm{~kW}$ electric motor and a $144 \mathrm{~V}, 6.5$ Ah Nickel-Metal Hydride battery. The Honda Insight's engine is a 3 cylinder, 1.0 liter, lean burn, VTEC engine with a maximum power of $50 \mathrm{~kW}(67$ $\mathrm{hp})$ at $5700 \mathrm{rpm}$ and a maximum torque of $90 \mathrm{Nm}(66 \mathrm{ft}-$ lb) at $4800 \mathrm{rpm}$. 
The integrated motor assist (IMA) system consists of a permanent magnet, DC brushless electric motor that is rated at $10 \mathrm{~kW}$ at $3000 \mathrm{rpm}$. The $60 \mathrm{~mm}$ wide motor is mounted to the crankshaft between the engine and transmission. As the name implies, the electric motor provides assist during vehicle accelerations. It functions as a generator during decelerations to capture braking energy. It is also used as a starter motor, and assists in balancing the 3-cylinder gasoline engine by damping engine-idle vibration by applying reverse torque to the crankshaft. Figure 1 shows how the engine and IMA system combine to provide the necessary vehicle driving power and torque ${ }^{1}$.

Along with the hybrid-electric powertrain, Honda focused on weight reduction, aerodynamic drag and rolling resistance, and engine efficiency ${ }^{1,2}$. Table A-1 in the appendix provides a summary of the vehicle specifications that apply to the modeling effort.

\section{VEHICLE INSTRUMENTATION AND DATA} COLLECTION - Test data was collected from three sources.

1. NREL's on-board data acquisition

2. OBDII automotive scantool

3. chassis dynamometer data acquisition

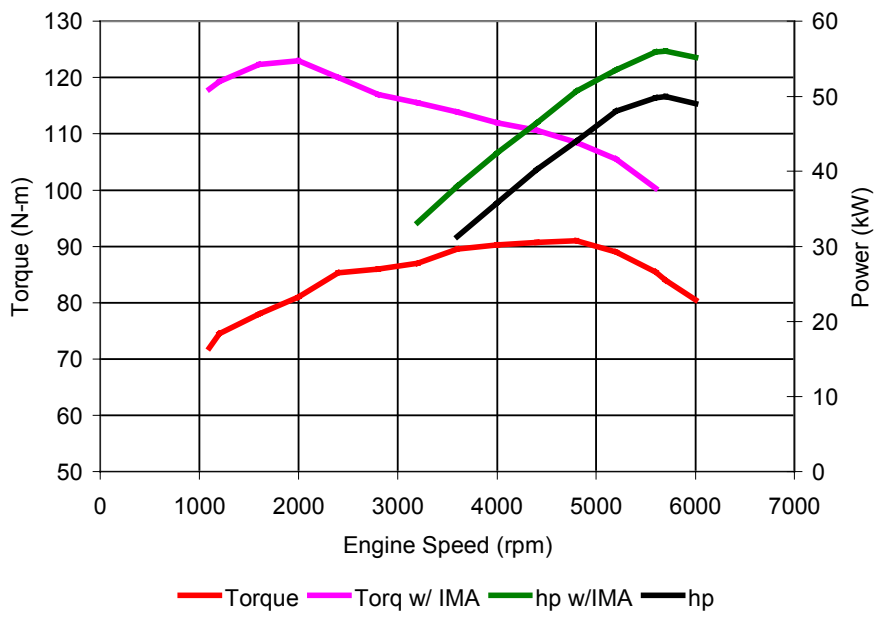

Figure 1 Honda Insight Power and Torque Curves

NREL's on-board data acquisition includes the following measurements

- battery cell temperatures

- battery cell voltages

- interior cabin temperatures

- battery pack current

- auxiliary loads current

- GPS coordinates, altitude, and speed

The following figures show the Insight instrumentation. Figures 2 and 3 show the Insight battery pack removed from the vehicle and undergoing instrumentation for cell temperature and voltages. Vehicle interior temperatures were measured for the passenger, driver, console, and roof. The battery pack currents $I_{\text {motor }}$ and $I_{\text {aux }}$ are measured as shown if Figure 4 using voltage shunts.

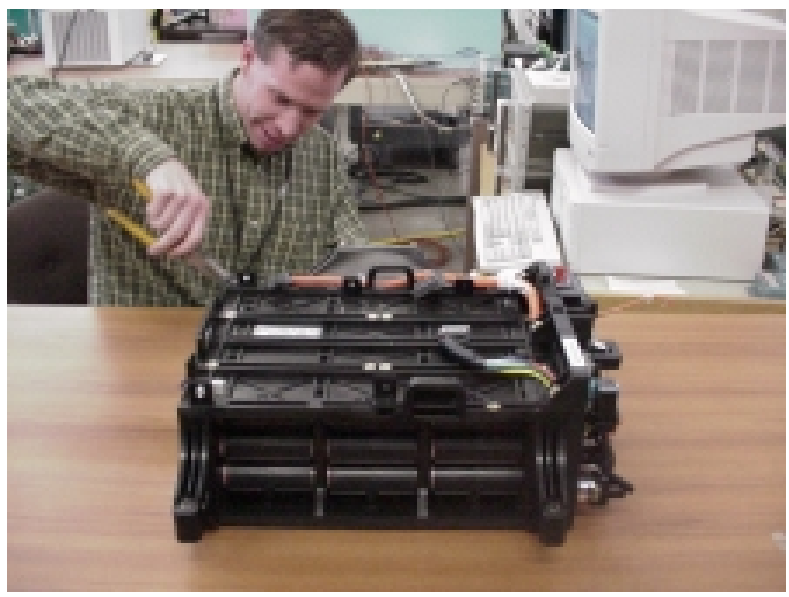

Figure 2 Insight Battery Pack Removed

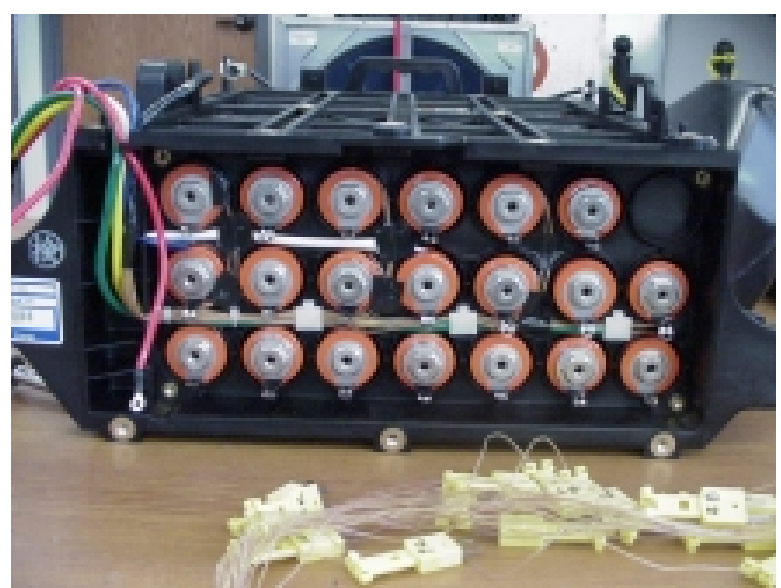

Figure 3 Insight Battery Pack end view showing thermocouples and voltage taps

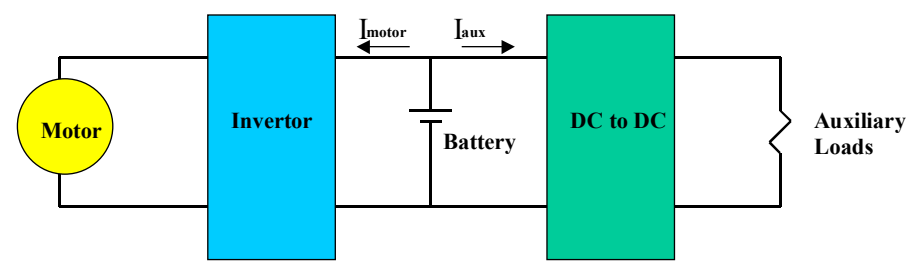

Figure 4 Location of measured currents

The OBDII Automotive Scantool is a commercially available software/hardware connection that taps into the on-board diagnostics (OBD) connector on the vehicle's computer to sample the following:

\footnotetext{
- vehicle speed

- engine rpm

- calculated load

- manifold air pressure

- throttle position
} 
- $\quad$ engine coolant temperature

- $\quad$ intake air temperature

- spark advance

- $\quad$ O2 sensor reading

- OBD diagnostic

Because the scan rate available is dependent on the number of channels sampled, only the channels considered most important for modeling purposes will be scanned. For example, initial tests were conducted with all channels being scanned at a rate of $0.2 \mathrm{~Hz}$, chassis dynamometer tests included 6 channels scanned at a rate of $1 \mathrm{~Hz}$, while vehicle acceleration tests included only two channels scanned at a rate of $3 \mathrm{~Hz}$.

Environmental Testing Corporation (ETC) is a privately owned emission testing facility located approximately 30 miles east of NREL in Aurora, Colorado. ETC is recognized by the EPA as a high-altitude emissions certification test laboratory. Data from ETC's test equipment was logged at $20 \mathrm{~Hz}$ and includes the following channels:

$\begin{array}{ll}\text { - } & \text { Distance } \\ \text { - } & \text { Time } \\ \text { - } & \text { Speed } \\ \text { - } & \text { Torque } \\ \text { - } & \text { Exhaust Flow Rate } \\ \text { - } & \text { Exhaust Volume } \\ \text { - } & \text { Ambient Volume } \\ \text { - } & \text { Dilution Rate } \\ \text { - } & \text { NOx Correction Factor } \\ \text { - } & \text { Absolute Humidity } \\ \text { - } & \text { Temperature } \\ \text { - } & \text { Barometric Pressure } \\ \text { - } & \text { HC (ppm and grams) } \\ \text { - } & \text { CO (ppm and grams) } \\ \text { - } & \text { NOx (ppm and grams) } \\ \text { - } & \text { CO } 2 \text { (\% and grams) } \\ \text { - } & \text { Motor Current } \\ \text { - } & \text { Auxiliary Current } \\ \text { - } & \text { Battery Voltage } \\ \text { - } & \text { Cabin Temperature }\end{array}$

The laboratory also reported results from the analysis of exhaust samples collected over the entire cycle and for individual test phases (referred to as bag analysis).

\section{TEST PROCEDURES AND RESULTS}

Environmental Testing Corporation in Aurora, Colorado was subcontracted to perform the following chassis dynamometer tests on the vehicle.

a) FTP-75 - Federal Test Procedure for emissions certification on a city cycle

b) Highway Fuel Economy Test (HWFET)

c) US06 aggressive driving cycle performed at $0^{\circ} \mathrm{C}, 20^{\circ} \mathrm{C}$, and $40^{\circ} \mathrm{C}$ d) $\mathrm{SC03}$ air conditioning cycle performed at $35^{\circ} \mathrm{C}$ with and without air conditioning

At least two repeats of each test procedure were conducted to assess repeatability. Table A-2 in the appendix shows a list of chassis dynamometer tests (with summary results) that were completed in July and August of 2000.

As stated earlier, the purpose of the testing and this analysis is focused on vehicle and component behavior more than overall emissions or fuel economy numbers. However, Figure 5 provides a summary of the average fuel economy results from each test procedure. One important point is the noticeable drop in fuel economy due to AC operation. The fuel economy measured over the SC03 cycle with the AC on was approximately $33 \%$ lower than that measured on the $\mathrm{SCO} 3$ without AC.

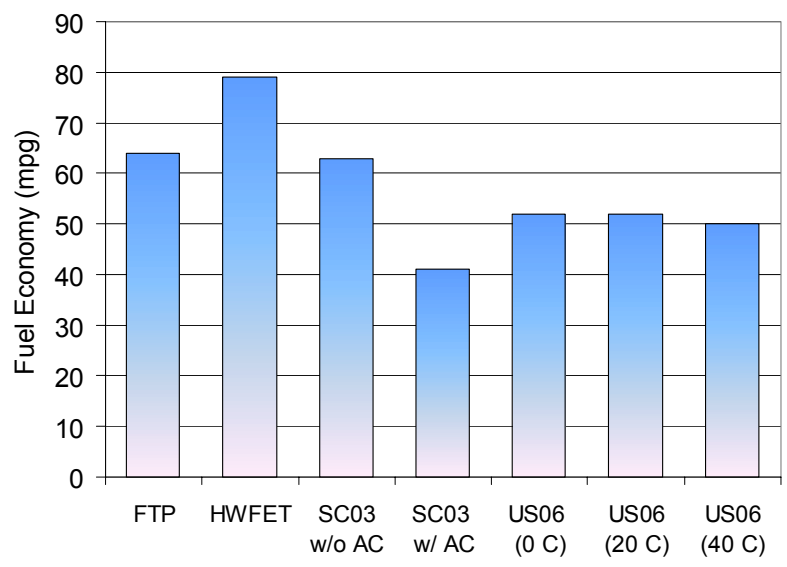

Figure 5 Summary of Fuel Economy Results

VEHICLE OPERATIONAL CHARACTERISTICS - Aside from the overall test results shown in the previous section, the detailed instrumentation and data acquisition allowed for investigation of vehicle and component operational characteristics. Understanding these characteristics is important for model development. There are four basic components to the Honda Insight HEV operational characteristics that the NREL testing highlights:

1. electric motor assist

2. regenerative braking

3. battery SOC control

4. idle-stop

The Honda Insight's electric motor provides added power to drivetrain during moderate to high load events. The same motor is also used as a generator to capture braking energy and store it in the battery. Figure 6 shows the battery pack voltage and current for a typical "hill" on the urban dynamometer driving schedule (UDDS). Negative values represent current being drawn from the pack during motor assist operation. Positive 
values represent charge currents to the pack such as during regenerative braking. During the FTP cycle, hard acceleration events were accompanied by current levels to the electric motor between 20 to 30 amps for motor input power levels between 2.5 and $4.5 \mathrm{~kW}$. Occasionally the motor input currents were as high as 40 amps (or $6 \mathrm{~kW}$ ). On the more aggressive US06 driving cycle the motor assist power levels were as high as 6.5 kW electric power into the motor. Power from the generator during regenerative braking events were often as high as $6 \mathrm{~kW}$ during the FTP cycle and between 7 to 9 $\mathrm{kW}$ during hard decelerations of the US06 cycle.

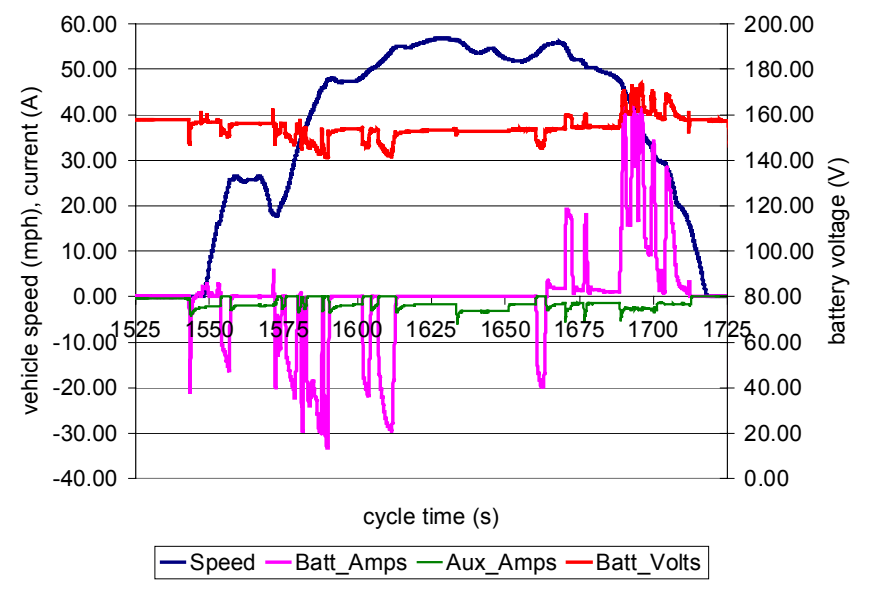

Figure 6 Sample of battery voltage and current from UDDS cycle

Figure 7 shows the total amount of energy in and out of the battery pack for each of the different cycles tested. The energy was calculated as the current to or from the pack multiplied by the pack voltage and integrated over time. For comparison purposes the energy (in Joules) was then divided by the cycle distance. The intent of this analysis is to show how much the motor-assist is used in different driving conditions. The average assist energy per mile over the HWFET cycle was approximately one-half of the energy use per mile of the FTP cycle. This is expected since the HWFET cycle includes fewer accelerations. The energy use per mile over the US06 cycle ranged from $190 \%$ to $255 \%$ of that used over the FTP cycle - with the highest value occurring on the $0^{\circ} \mathrm{C}$ test and the lowest value during the $40^{\circ} \mathrm{C}$ test. Current limiting to help prevent battery over-heating was observed during the US06 test, and this may explain the trend associated with ambient temperature. For the $\mathrm{SC0} 3$ test without $\mathrm{AC}$, the average assist energy used per mile for motor assist was $185 \%$ of that for the FTP, but when the AC was turned on the average energy use per mile was over 3 times that used for the FTP. This was most likely caused by the need for more power due to the extra load placed on the engine by the $\mathrm{AC}$ compressor.

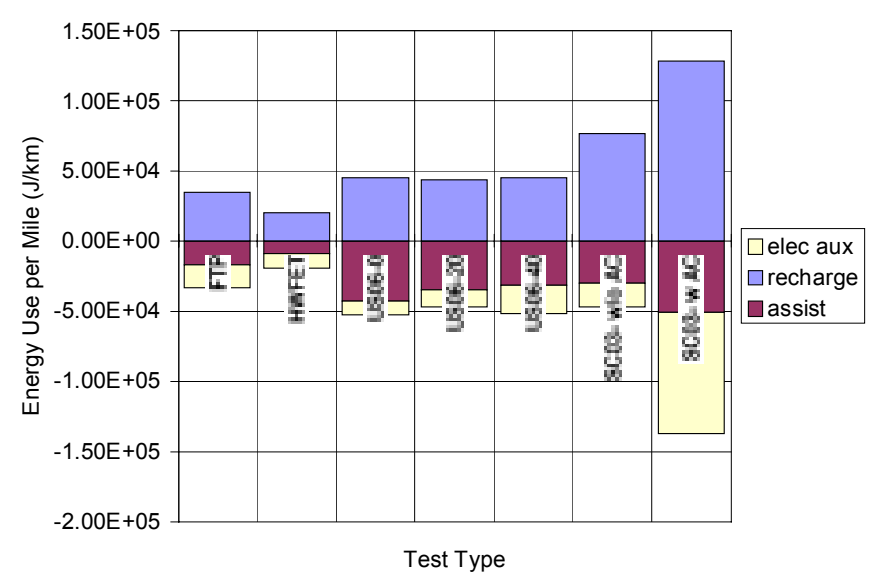

Figure 7 Total Energy Use Over Various Driving Cycles

In general the amount of recharge energy is similar to the total amount of energy drawn from the pack (motor assist plus electrical auxiliaries). The energy used by electrical auxiliaries varied significantly from cycle to cycle. The amount of electrical auxiliary energy used was related to the temperature of the battery pack, since the battery has a fan that circulates cabin air through the pack to cool it. The other major contributor to the amount of electrical energy used for auxiliary systems is the air conditioning fan. The Insight's AC compressor is mechanically driven off the engine. Use of the air conditioner caused a five-fold increase in auxiliary electrical energy from approximately 1 Joule without AC to 5 Joules with AC over the $\mathrm{SCO} 3$ cycle.

Chassis dynamometer testing and on-road driving experience revealed that the Honda Insight tends to maintain a relatively high indicated battery state of charge. To better understand the battery SOC condition and to ensure repeatable SOC from test to test, NREL developed a battery SOC prep procedure. The procedure involved fully charging and discharging the battery on-board the vehicle. Battery charging was accomplished by using the dynamometer to drive the vehicle's wheels at a constant $51 \mathrm{mph}$ until the battery would no longer accept current. This is analogous to coasting down a long steep grade. Discharging was accomplished by then shifting into high gear and attempting to overcome the dynamometer loading (similar to attempting to climb a steep grade in high gear) until the control strategy would no longer allow current to be drawn from the pack. Data from this procedure is shown in figure 8 . 


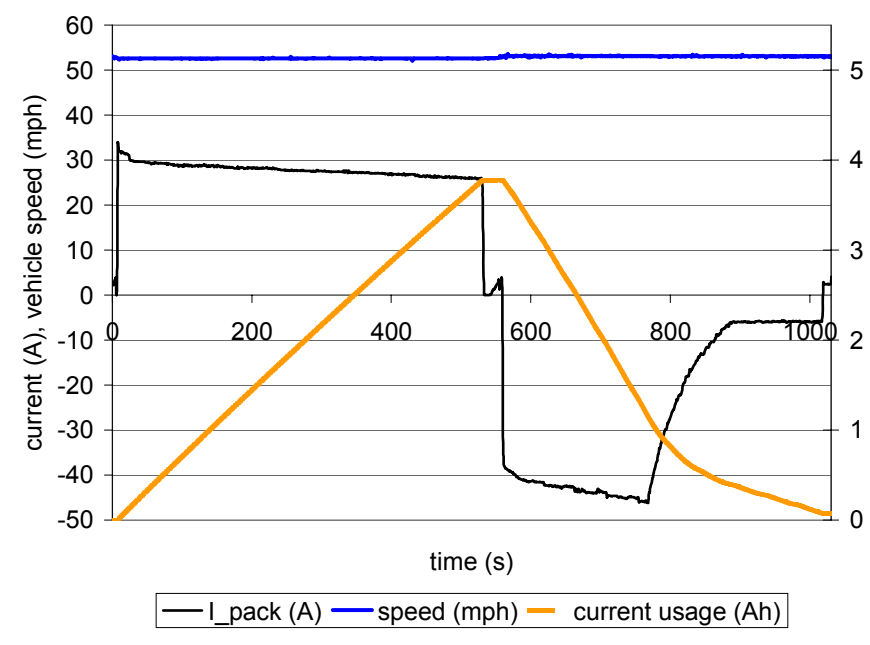

Figure 8 In-vehicle Charging and Discharging of the Battery Pack

On the left side of the graph the battery is being charged. Starting from fully discharged, it accepts approximately 3.8 Ah of charge at charging current ranging from 32 to $25 \mathrm{~A}$. On the discharge side, the battery is discharged by supplying current to the motor to assist in driving the vehicle. The battery put out approximately 3.0 Ah at a discharge current that, at first, ranged from 38 to $46 \mathrm{~A}$ and then dropped down to $6 \mathrm{~A}$ before the battery no longer supplied current to the motor. The charge and discharge limits define the usable capacity of the battery that is set by the vehicle control strategy and is approximately $3.8 / 6.5=58 \%$ of the full rated capacity of the battery.

A similar procedure was performed on the highway and is shown in figure 9. The data shown is from a highway test drive of the Insight starting at the top of a mountain at an elevation of $7800 \mathrm{ft}$ and descending $2000 \mathrm{ft}$, and then climbing back up at highway speeds. In this case regenerative braking currents hovered around $20 \mathrm{~A}$, or about $3.5 \mathrm{~kW}$ power, when coasting down, and increased to as high as $50 \mathrm{~A}$ (or about $8 \mathrm{~kW}$ ) when the brake pedal was applied. On the uphill portion of the drive, the motor input currents initially ranged between 40 to $45 \mathrm{~A}(6.4 \mathrm{~kW})$, but then gradually decreased to around $6 \mathrm{~A}(1.3 \mathrm{~kW})$ before going to zero near the top of the grade.

During this exercise, the vehicle exhibited behavior similar to that experienced on the dynamometer, and a few additional points were highlighted. First this data clearly shows two modes of regenerative braking - with braking and without braking. This data also provides a real-world example of the limitations of the battery pack to provide power for motor assist during a long steep grade. Also, during the first of these hill climbs, an increase in average battery pack temperature from $21^{\circ} \mathrm{C}$ to $33^{\circ} \mathrm{C}$ was observed. Increases in battery temperature were also observed during chassis testing and are believed to play a part in the control strategy limitations on power output from the pack ${ }^{3}$.

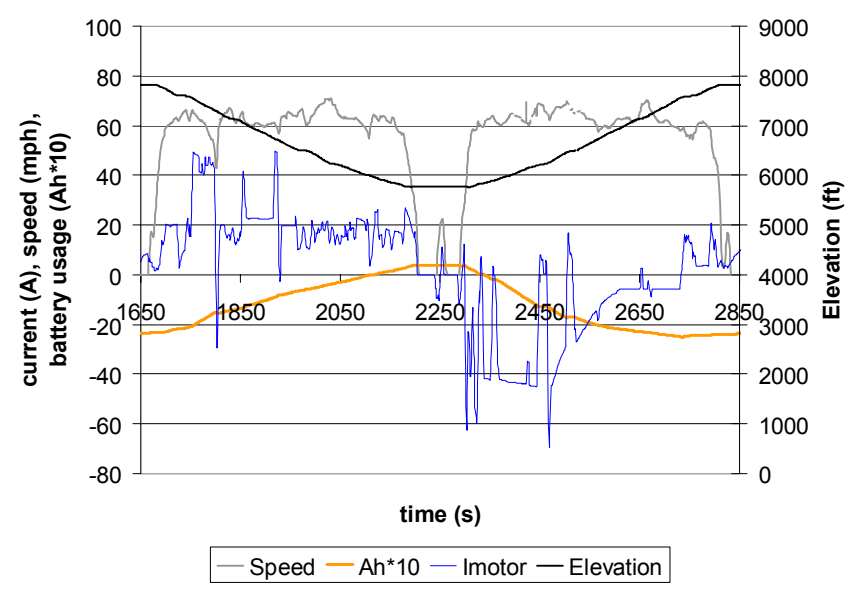

Figure 9 Battery Performance on a Steep Highway Grade

Figure 10 shows three Ah profiles for the Federal Urban Dynamometer Driving Schedue (UDDS), which is the first two phases of the FTP-75 test procedure. These tests were all performed with an initial SOC at approximately $50 \%$ (defined by bringing the battery to full charge as described above and then discharging $50 \%$ of the useful capacity). Although the final Ah varied from -0.01 (net discharge of $0.15 \%$ of the rated Ah capacity) to 0.15 (net charge of $2.3 \%$ of the rated Ah capacity), the profile for each test was very similar. The FTP75 battery usage is characterized by an initial discharge over the first two "hills" of the cycle, followed by a long net charging portion with small intermediate charges and discharges along the way.

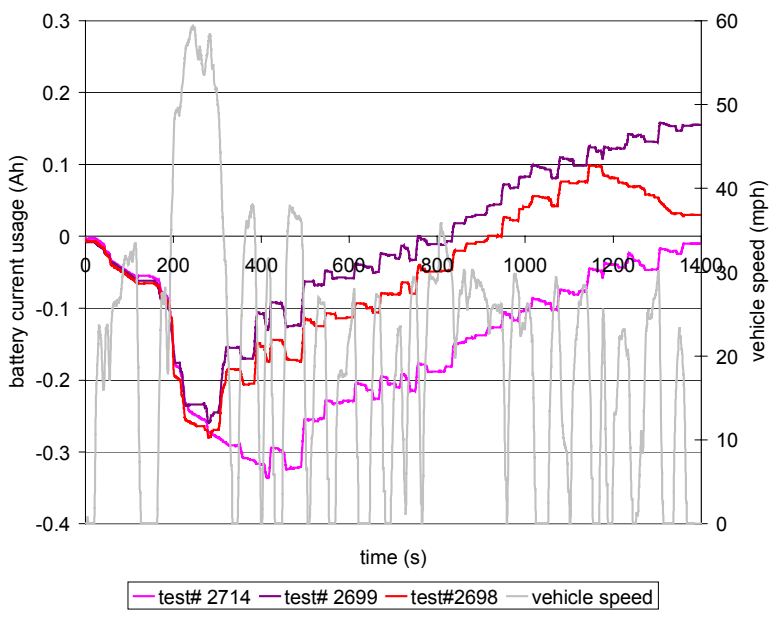

Figure 10 Battery Usage during UDDS 
Figure 11 shows two Ah profiles for the US06 driving schedule. These tests were also performed at an initial SOC of approximately $50 \%$, but a warm-up US06 driving cycle was driven just before the driving cycle shown. As with the UDDS, the capacity used is somewhat different for the two tests, but the profiles are similar. This is a more aggressive driving cycle than the UDDS and is characterized by more frequent and aggressive discharge and charging portions.

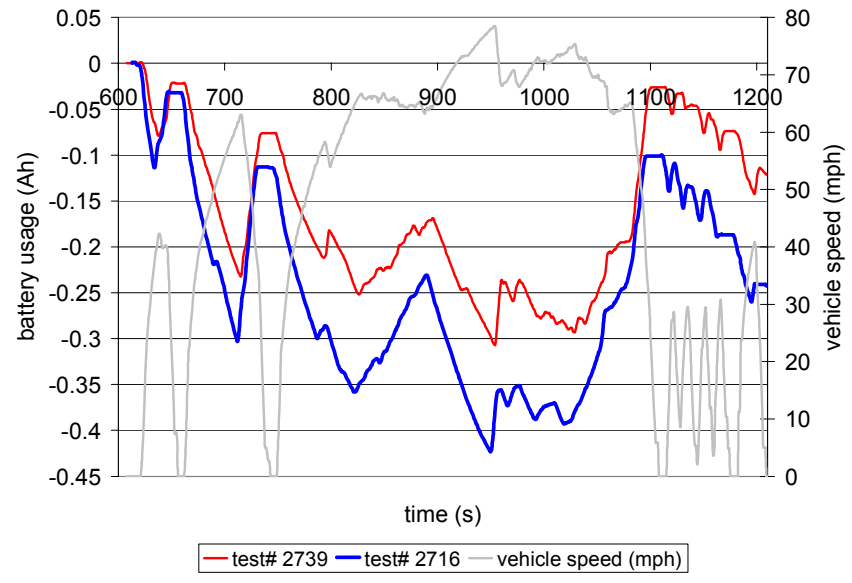

Figure 11 Battery Usage during the US06 Test

The idle-stop feature on the Insight engages when the vehicle is at rest or when it is decelerating below $20 \mathrm{mph}$ and is in neutral. This is shown from the test data in figure 12. In this example from the FTP75 test the engine speed goes to zero instead of idling as the vehicle is decelerating to a stop. This is an important feature since the FTP75, which is used to determine city fuel economy ratings includes 22 stops over the cycle.

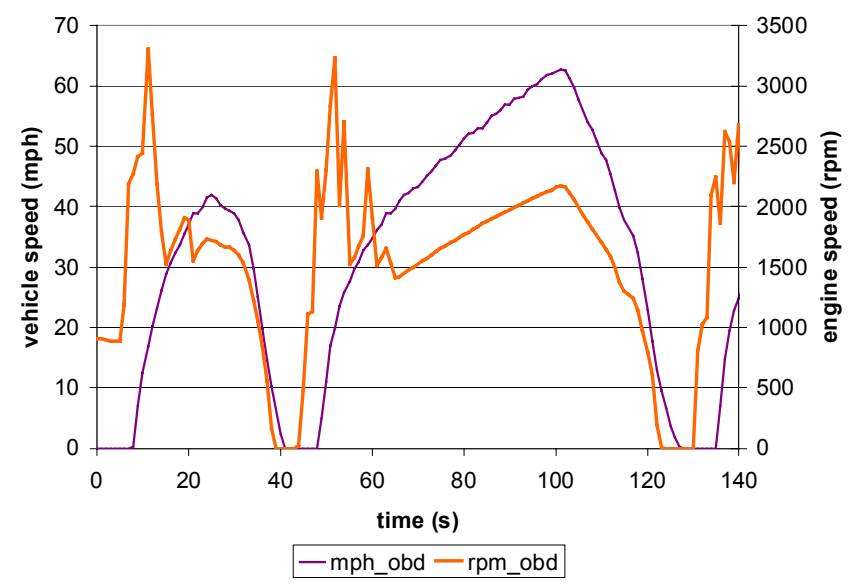

Figure 12 Idle Stop Feature Engaged during the FTP75

\section{VEHICLE MODELING}

Any vehicle model in ADVISOR includes two main elements; the controlling block diagram and the vehicle and component input data.

BLOCK DIAGRAM - The main block diagram for the ADVISOR model of the Honda Insight is shown in figure 13. This figure also illustrates the backward facing architecture of the model. Information flows from the drive cycle speed requirements through the drivetrain to calculate outputs of the fuel converter, electric motor, and energy storage device. Feedback signals of the achievable output for each component are calculated and the power requirements are adjusted based on what was achieved in the previous time step.

The control strategy used in the Insight model is similar to the ADVISOR's standard starter-alternator control strategy except in the control of the engine-on logic contained in the Insight vehicle controls $(\langle\mathrm{vc}\rangle)$ block. For the Honda Insight, the gasoline engine remains on in most cases. The following criteria define when the engine is allowed to shut off. As in the actual vehicle, the engine in ADVISOR's model of the Insight has been programmed to shut down only when the following conditions are met:

1. engine is warm (as determined from coolant temperature)

2. battery SOC is greater than the low SOC set point

3. vehicle is decelerating or stopped

4. vehicle speed is less than $9 \mathrm{~m} / \mathrm{s}(20 \mathrm{mph})$

5. vehicle is not shifting gears

A boolean (decel_fc_off) was also added to allow for an override of the engine-off condition during low speed decelerations. When driving the actual vehicle, this can be done by not putting the vehicle in neutral during decelerations. The boolean is defined in the powertrain control file (PTC_INSIGHT) and has a default value of 1 ( 1 allows the engine to shut off during decel, 0 keeps the engine on during decel). 


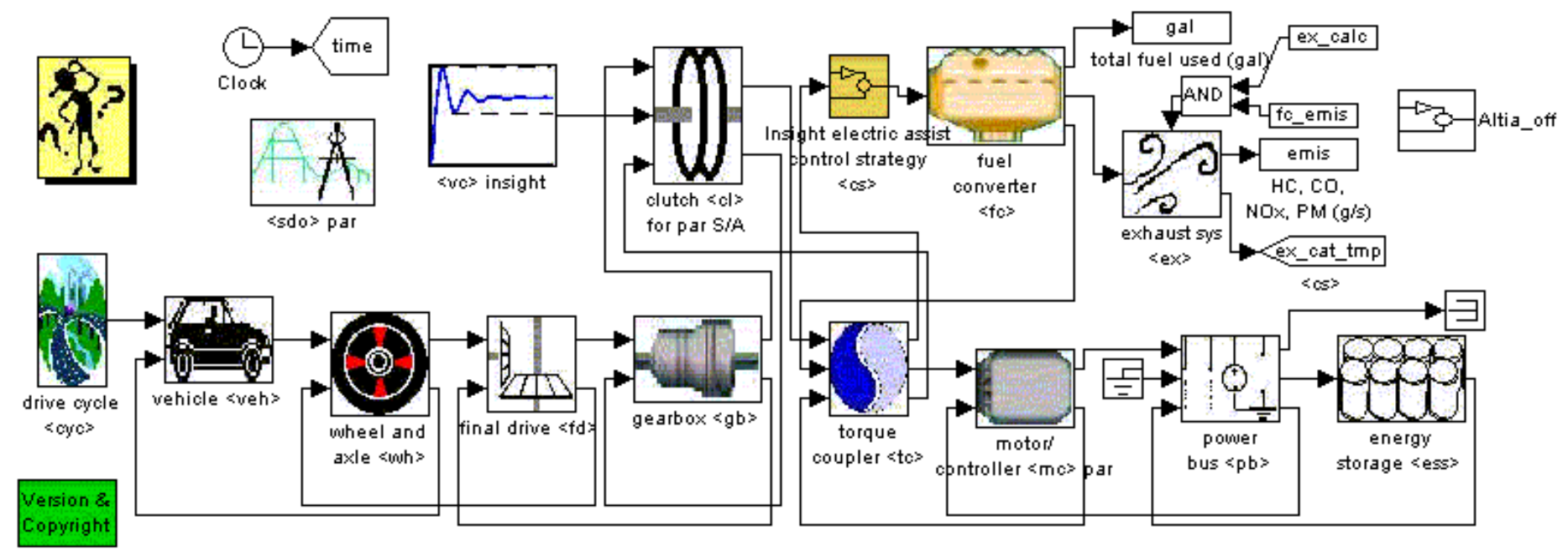

Figure 13 Main Block Diagram for ADVISOR's Insight Model

VEHICLE INPUT PARAMETERS - Table A-1 in the appendix shows the main input parameters for the Insight model along with the ADVISOR input filename. The following information describes main parameters defined in the Insight vehicle setup files. Most of this information was obtained from published sources ${ }^{1,2,4}$. Additionally, ADVISOR requires an engine map, motor map, battery internal resistances. The engine map was supplied by Argonne National Laboratory (ANL) based on testing at their facility. The battery internal resistances were measured at NREL's Battery Thermal Management Lab. The motor map was taken from an existing electric motor map in ADVISOR and modified with the peak power requirements.

The engine map from ANL is shown in Figure 14.

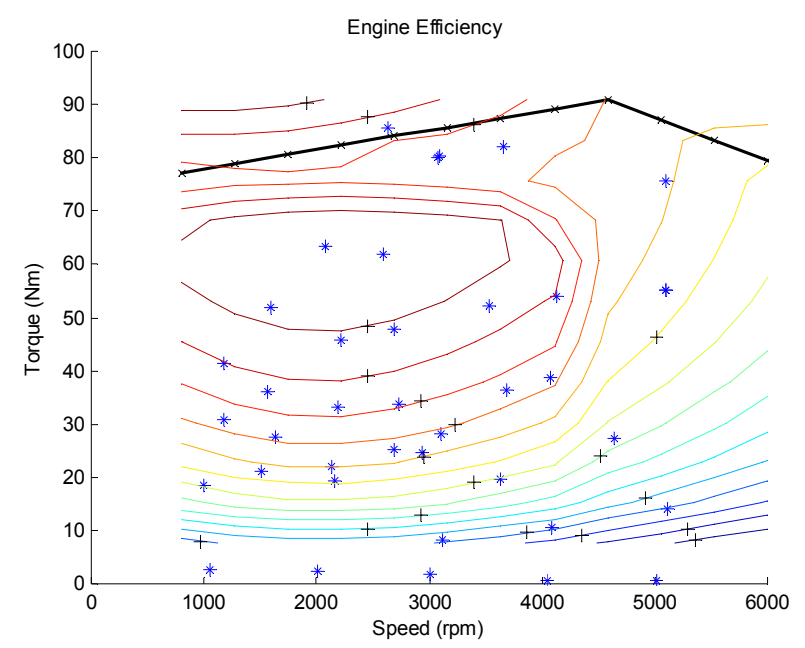

Figure 14 Honda Insight Engine Map
The battery pack in the Honda Insight is a $144 \mathrm{~V}$ nickelmetal hydride battery comprised of 20 modules with 6 $1.2 \mathrm{~V}$ cells in each module. The rated capacity is $6.5 \mathrm{Ah}$. NREL's Battery Thermal Management team conducted testing on the pack to determine the pack internal resistances shown in figure 15 . These hybrid pulse power characterization tests were performed according to procedures defined by the Partnership for a New Generation of Vehicles' Battery Test Manual ${ }^{5}$.

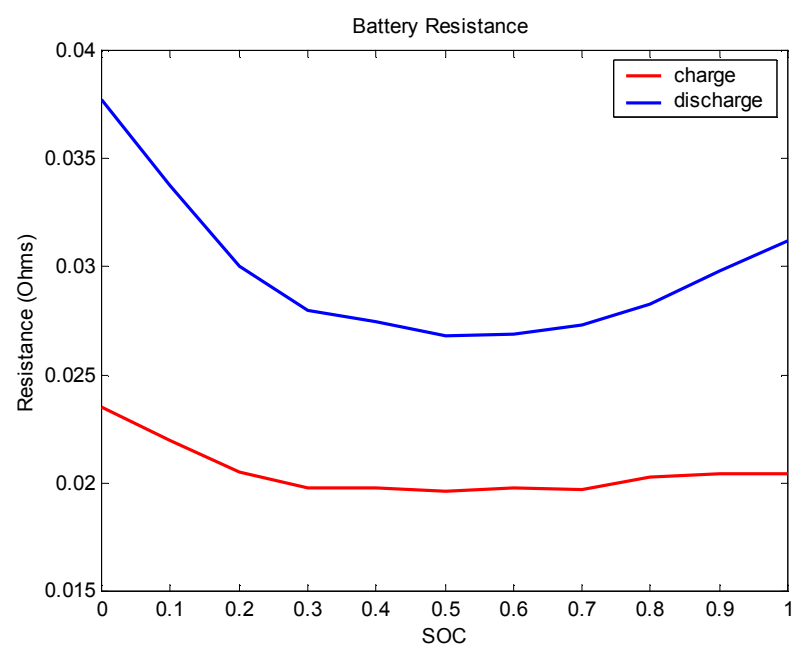

Figure 15 Insight Battery Internal Resistance

The electric motor model was derived from an existing DC permanent magnet electric motor included in ADVISOR (Data Source: Honda R\&D Americas). This is a $49 \mathrm{~kW}$ motor that was scaled down to $10 \mathrm{~kW}$. Maximum torque points were derived from published speed vs. torque for the Insight engine and engine with integrated 
motor assist ${ }^{1}$. Key operating points that were incorporated into the model include:

- power - $10 \mathrm{~kW}$ at $3000 \mathrm{rpm}$

- peak power of engine plus integrated motor assist $54.4 \mathrm{~kW}$ at $5700 \mathrm{rpm}$

- peak torque of engine plus integrated motor assist $123.4 \mathrm{Nm}$

- mass $-60 \mathrm{~kg}$

ADVISOR's standard close-coupled catalyst is used in the current model. The Insight catalyst is a lean-burn, $\mathrm{NO}_{\mathrm{x}}$ adsorption catalyst that is close coupled to the engine. An improved catalyst model will be incorporated as data becomes available.

The Insight tire model is derived from ADVISOR's small car wheel model. The only update to this file is the wheel radius $(0.275 \mathrm{~m})$, which was calculated from $\mathrm{mph} / 1000 \mathrm{rpm}$ data published by Car\&Driver ${ }^{4}$.

Table 1 Honda Insight Published Speeds at $1000 \mathrm{rpm}$

\begin{tabular}{|c|c|c|}
\hline gear & $\begin{array}{c}\text { Speed } \\
(\mathrm{mph} / 1000 \mathrm{rpm})\end{array}$ & $\begin{array}{c}\text { gear } \\
\text { ratio }\end{array}$ \\
\hline 1st & 5.8 & 3.46 \\
\hline 2nd & 11.5 & 1.75 \\
\hline 3rd & 18.3 & 1.1 \\
\hline 4th & 23.4 & 0.86 \\
\hline 5th & 28.3 & 0.71 \\
\hline
\end{tabular}

The Insight's powertrain control model was modified from ADVISOR's standard parallel powertrain control file. Insight engine's idle speed $94 \mathrm{rad} / \mathrm{s}$ (900 rpm) was taken from from NREL testing. Two parameters were added:

- decel_fc_off allows the engine to be shut off during low speed decelerations,

- cs_electric_decel_spd $=9 \mathrm{~m} / \mathrm{s}(20 \mathrm{mph})$ defines the vehicle speed below which the engine can shut off.

SIMULATION RESULTS - ADVISOR allows for simulations of all of the chassis dynamometer test procedures mentioned previously as well as many other standard driving cycles, and any user defined cycles.

Table 2 provides a comparison of the fuel economy results predicted by the ADVISOR simulations of the Honda Insight to published data and NREL test results. The table also shows comparisons between ADVISOR predicted acceleration times, published data, and NREL track tests.

ADVISOR's predicted fuel economy was within $2 \%$ of the published EPA values. The predicted values were somewhat higher than NREL test results. However, it should be noted that these tests were conducted at high altitude where fuel economy numbers are expected to be lower.
Table 2 Comparison of Results from ADVISOR

\begin{tabular}{|c|c|c|c|}
\hline & \begin{tabular}{|l|} 
ADVISOR \\
Release 3.1
\end{tabular} & $\begin{array}{l}\text { Published } \\
\text { Data* }^{*}\end{array}$ & \begin{tabular}{|l|} 
NREL \\
Test Data
\end{tabular} \\
\hline \multicolumn{4}{|c|}{ Fuel Economy (mpg) } \\
\hline FTP75 & 66.8 & 65.6 & 64.1 \\
\hline HWFET & 88.2 & 89.9 & 79.0 \\
\hline US06 & 56.8 & $\mathrm{n} / \mathrm{a}$ & 52.3 \\
\hline $\mathrm{SC03}$ & 66.0 & $\mathrm{n} / \mathrm{a}$ & 62.7 \\
\hline \multicolumn{4}{|c|}{ Vehicle Acceleration (s) } \\
\hline $0-30$ & 4.0 & 3.6 & 4.5 \\
\hline $0-40$ & 6.7 & 5.9 & 7.3 \\
\hline $0-50$ & 9.5 & 8.9 & 10.6 \\
\hline $0-60$ & 12.5 & 12.3 & 14.6 \\
\hline $0-70$ & 16.9 & 16.7 & 19.2 \\
\hline $0-80$ & 23.1 & 24.4 & $\mathrm{n} / \mathrm{a}$ \\
\hline $0-90$ & 30.2 & 34 & $\mathrm{n} / \mathrm{a}$ \\
\hline $\begin{array}{c}1 / 4 \text { mile } \\
\text { time }\end{array}$ & 19.2 & 18.8 & $\mathrm{n} / \mathrm{a}$ \\
\hline
\end{tabular}

The acceleration times predicted by ADVISOR were within $12 \%$ of the published data. Acceleration time from 0 to $60 \mathrm{mph}$ and the quarter-mile time both were within $2 \%$ of the published values. It should be noted that the published values are described as partial charge results. The ADVISOR simulations were run starting at $50 \%$ state of charge. NREL tests were somewhat slower than either the ADVISOR predictions or published results. This is likely due to the lack of professional drivers and high altitude testing.

In its results screen, ADVISOR allows the user to view detailed second-by-second performance of a wide array of vehicle and component parameters. Figure 16 shows a comparison of the predicted and actual measured battery current during a portion of the US06 cycle. In

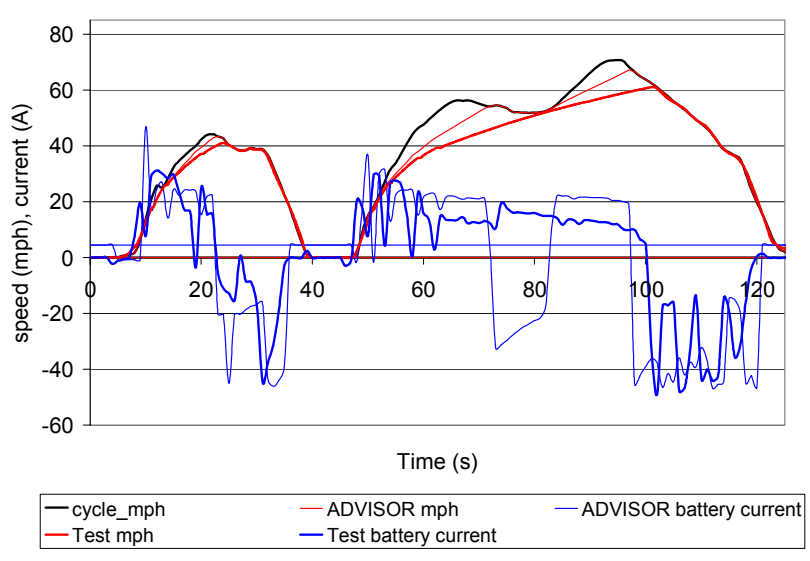

Figure 16 ADVISOR Predicted and Measured Current during the US06 cyle 
this snapshot, the magnitude and location of the predicted current flow agrees well with the actual measured values. Note that the vehicle did not meet the US06 driving cycle trace using the shift schedule provided.

Another example is shown in figure 17 that compares predicted and actual measured engine speed during a portion of the FTP75 test procedure. The predicted engine speed is very close to the measured speed except in several cases where the speed dependent shifting logic in ADVISOR caused a gear shift that was not executed by the driver during the test procedure.

Figure 17 also illustrates how ADVISOR accurately models the Insight's idle stop feature. Near the end of the time period shown, as the vehicle is slowing down, the engine shuts off (rpm's go to 0 ) rather than idle.

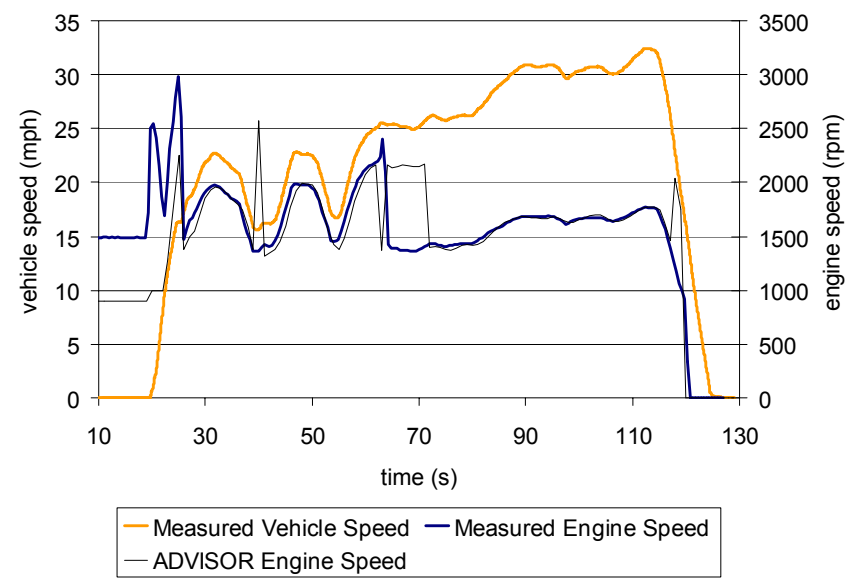

Figure 17 ADVISOR Predicted and Measured Engine Speed during the FTP cycle

\section{CONCLUSION}

Through vehicle testing under standard conditions and with detailed component instrumentation NREL has shown how the Insight performs, and revealed some of the finer points of the vehicle's control strategy and component operation. Data from the testing and from other published sources has allowed NREL to build an accurate model of the Insight in ADVISOR. Predicted results and operational characteristics are in good agreement with the actual vehicle performance and component operation.

\section{ACKNOWLEDGMENTS}

This work was funded by the U.S. Department of Energy's Office of Advanced Transportation Technologies as part of the Vehicle Systems team. We wish to thank Robert Kost (DOE HEV program manager) and Terry Penney (NREL HEV technology manager) for their continued support. We would also like to acknowledge the contribution of Argonne National Laboratory for providing additional vehicle test data, the Battery Thermal Management team at NREL for vehicle instrumentation, data acquisition, and battery testing, and Environmental Testing Corporation's high quality and flexible vehicle testing.

\section{REFERENCES}

1. Knight, B, "Insight - A Motor Assist Hybrid", Honda R\&D Americas, Presentation to Ultra Clean Vehicle Workshop, November, 301999.

2. Yamaguchi, J., Insight by Honda, Automotive Engineering International, Society of Automotive Engineers October 1999.

3. Zolot, M., Keyser, M., Mihalic, M., Pesaran, A.A., Kelly, K.J., Hieronymus, A. "Thermal Evaluation of the Honda Insight Battery Pack", IECEC2001-ET-07, Proceedings of the $36^{\text {th }}$ IECEC Conference, August 2001.

4. Neil, D, "Honda Insight", Car and Driver, January 2000.

5. U.S. Dept of Energy PNGV Battery Testing Manual, Revision 2, August 1999. 


\section{APPENDIX}

Table A-1 Honda Insight Vehicle Parameters used in ADVISOR

\begin{tabular}{|c|c|c|c|c|}
\hline $\begin{array}{l}\text { Vehicle } \\
\text { Component }\end{array}$ & $\begin{array}{l}\text { ADVISOR Input } \\
\text { Filename }\end{array}$ & Input Parameter & Value & Units \\
\hline \multirow[t]{8}{*}{ Vehicle } & \multirow[t]{8}{*}{ VEH_INSIGHT } & vehicle mass & 800 & $\mathrm{~kg}$ \\
\hline & & battery mass & 20 & $\mathrm{~kg}$ \\
\hline & & engine mass & 60 & $\mathrm{~kg}$ \\
\hline & & vehicle height & 1.325 & $\mathrm{~m}$ \\
\hline & & vehicle width & 1.695 & $\mathrm{~m}$ \\
\hline & & aerodynamic drag coefficient & 0.25 & \\
\hline & & fronal area & 1.9 & $\mathrm{~m} 2$ \\
\hline & & wheelbase & 2.4 & $\mathrm{~m}$ \\
\hline \multirow[t]{2}{*}{ Engine } & \multirow[t]{2}{*}{ FC_INSIGHT } & peak power & 50 & $\begin{array}{c}\mathrm{kW} \text { at } \\
5700 \mathrm{rpm}\end{array}$ \\
\hline & & peak torque & 89.5 & $\begin{array}{c}\mathrm{Nm} \text { at } \\
4800 \mathrm{rpm}\end{array}$ \\
\hline \multirow[t]{5}{*}{ Battery } & \multirow[t]{5}{*}{ ESS_INSIGHT } & battery type & $\mathrm{NiMH}$ & \\
\hline & & cell voltage (nominal) & 1.2 & V \\
\hline & & number of cells & 120 & \\
\hline & & pack voltage (nominal) & 144 & $\mathrm{~V}$ \\
\hline & & rated capacity & 6.5 & Ah \\
\hline \multirow[t]{6}{*}{ Transmission } & \multirow[t]{6}{*}{ |TX_5SPD_SI } & final drive & $3.21: 1$ & \\
\hline & & 1st gear ratio & 3.46 & \\
\hline & & 2nd gear ratio & 1.75 & \\
\hline & & 3rd gear ratio & 1.1 & \\
\hline & & 4th gear ratio & 0.86 & \\
\hline & & 5th gear ratio & 0.71 & \\
\hline
\end{tabular}


Table A-2 Summary of Results from Chassis Dynamometer Testing

\begin{tabular}{|c|c|c|c|c|c|c|c|c|}
\hline \multirow[b]{2}{*}{$\begin{array}{l}\text { ETC Test } \\
\text { Number }\end{array}$} & \multirow[b]{2}{*}{$\begin{array}{l}\text { Test } \\
\text { Date }\end{array}$} & \multirow[b]{2}{*}{$\begin{array}{l}\text { Test } \\
\text { Type }\end{array}$} & \multirow[b]{2}{*}{$\begin{array}{l}\text { Test } \\
\text { Temp (F) }\end{array}$} & \multirow{2}{*}{\begin{tabular}{|l} 
Fuel \\
Economy \\
(mpg)
\end{tabular}} & \multicolumn{4}{|c|}{ Emissions $(\mathrm{g} / \mathrm{mi})$} \\
\hline & & & & & $H C$ & $\mathrm{CO}$ & $N O_{x}$ & $\mathrm{CO}_{2}$ \\
\hline 2698 & 01-Aug-00 & FTP75 & 75.2 & 65.7 & $\begin{array}{l}0.023 \\
\end{array}$ & 0.133 & 0.022 & 135.0 \\
\hline 2699 & 02-Aug-00 & FTP75 & 74.1 & 64.2 & 0.022 & 0.144 & 0.025 & 138.1 \\
\hline \multirow[t]{2}{*}{2714} & 10-Aug-00 & FTP75 & 74.8 & 62.4 & 0.024 & 0.159 & 0.020 & 142.1 \\
\hline & & & Average & 64.1 & 0.023 & 0.145 & 0.022 & 138.4 \\
\hline 2684 & 28-Jul-00 & HWFET & 75.0 & 78.8 & 0.001 & 0.161 & 0.031 & 112.5 \\
\hline 2685 & 28-Jul-00 & HWFET & 74.9 & 79.8 & 0.001 & 0.162 & 0.040 & 111.1 \\
\hline 2709 & 09-Aug-00 & HWFET & 75.2 & 78.5 & 0.003 & 0.146 & 0.037 & 113.0 \\
\hline \multirow[t]{2}{*}{2710} & 09-Aug-00 & HWFET & 74.8 & 78.8 & 0.001 & 0.117 & 0.045 & 112.5 \\
\hline & & & Average & 79.0 & 0.002 & 0.147 & 0.038 & 112.3 \\
\hline 2692 & 31-Jul-00 & SC03 with AC off & 94.9 & 63.5 & 0.005 & 0.255 & 0.094 & 139.5 \\
\hline 2693 & 31-Jul-00 & SC03 with AC off & 96.8 & 65.6 & 0.004 & 0.171 & 0.078 & 135.2 \\
\hline 2721 & 11-Aug-00 & SC03 with AC off & 95.4 & 63.4 & 0.010 & 0.206 & 0.043 & 139.8 \\
\hline \multirow[t]{2}{*}{2722} & 11-Aug-00 & SC03 with AC off & 95.6 & 58.5 & 0.006 & 0.244 & 0.044 & 151.6 \\
\hline & & & Average & 62.7 & 0.006 & 0.219 & 0.065 & 141.5 \\
\hline 2696 & 31-Jul-00 & SC03 with AC on & 95.7 & 42.8 & 0.004 & 0.663 & 0.024 & 206.7 \\
\hline 2697 & 31-Jul-00 & SC03 with $\mathrm{AC}$ on & 95.2 & 42.3 & 0.009 & 0.880 & 0.095 & 209.4 \\
\hline 2723 & 14-Aug-00 & SC03 with AC on & 95.0 & 40.5 & 0.006 & 0.658 & 0.100 & 218.3 \\
\hline \multirow[t]{2}{*}{2733} & 15 -Aug-00 & SC03 with AC on & 95.0 & 41.2 & 0.007 & 0.694 & 0.071 & 214.7 \\
\hline & & & Average & 41.7 & 0.007 & 0.724 & 0.073 & 212.3 \\
\hline 2687 & 28-Jul-00 & US06 & 75.0 & 52.7 & 0.014 & 3.014 & 0.008 & 163.8 \\
\hline 2688 & 28-Jul-00 & US06 & 75.5 & 53.1 & 0.009 & 3.070 & 0.007 & 162.5 \\
\hline 2689 & 31-Jul-00 & US06 & 81.1 & 52.7 & 0.009 & 2.705 & 0.076 & 164.4 \\
\hline 2716 & 10-Aug-00 & US06 & 74.5 & 51.8 & 0.009 & 2.670 & 0.005 & 167.4 \\
\hline \multirow[t]{2}{*}{2739} & 16-Aug-00 & US06 & 77.9 & 51.4 & 0.006 & 3.740 & 0.006 & 166.9 \\
\hline & & & Average & 52.3 & 0.009 & 3.040 & 0.020 & 165.0 \\
\hline 2691 & 31-Jul-00 & US06 & 103.2 & 52.7 & 0.015 & 2.831 & 0.241 & 164.1 \\
\hline 2729 & 14-Aug-00 & US06 & 105.7 & 51.4 & 0.013 & 3.720 & 0.004 & 167.1 \\
\hline \multirow[t]{2}{*}{2736} & 15 -Aug-00 & US06 & 105.0 & 52.6 & 0.008 & 3.112 & 0.002 & 164.0 \\
\hline & & & Average & 52.2 & 0.0120 & 3.221 & 0.082 & 165.0 \\
\hline 2743 & & US06 & 32.0 & 49.7 & 0.008 & 3.382 & 0.004 & 173.5 \\
\hline \multirow[t]{2}{*}{2750} & & US06 & 32.0 & 49.8 & 0.007 & 3.146 & 0.008 & 173.5 \\
\hline & & & Average & 49.7 & 0.008 & 3.264 & 0.006 & 173.5 \\
\hline
\end{tabular}




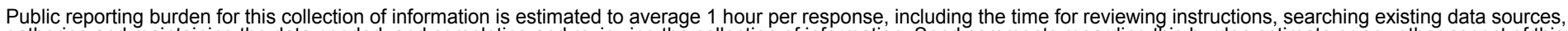

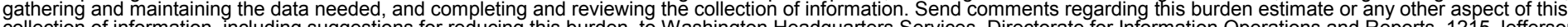

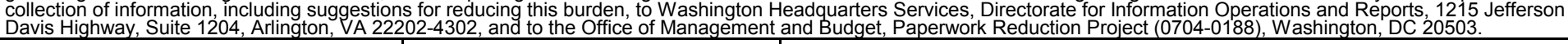
1. AGENCY USE ONLY (Leave blank)
2. REPORT DATE
November 2001
3. REPORT TYPE AND DATES COVERED Conference paper

\section{TITLE AND SUBTITLE \\ Test Results and Modeling of the Honda Insight using ADVISOR}

5. FUNDING NUMBERS HV116010

6. $\mathrm{AUTHOR}(\mathrm{S})$

Kelly, K.

Zolot, M.

7. PERFORMING ORGANIZATION NAME(S) AND ADDRESS(ES)

8. PERFORMING ORGANIZATION REPORT NUMBER

9. SPONSORING/MONITORING AGENCY NAME(S) AND ADDRESS(ES) National Renewable Energy Laboratory

1617 Cole Blvd.

10. SPONSORING/MONITORING AGENCY REPORT NUMBER

Golden, CO 80401-3393

NREL/CP-540-31085

11. SUPPLEMENTARY NOTES

12a. DISTRIBUTION/AVAILABILITY STATEMENT

National Technical Information Service

12b. DISTRIBUTION CODE

U.S. Department of Commerce

5285 Port Royal Road

Springfield, VA 22161

13. ABSTRACT (Maximum 200 words)

14. SUBJECT TERMS

15. NUMBER OF PAGES

16. PRICE CODE

17. SECURITY CLASSIFICATION OF REPORT Unclassified
18. SECURITY CLASSIFICATION OF THIS PAGE Unclassified
19. SECURITY CLASSIFICATION OF ABSTRACT Unclassified
20. LIMITATION OF ABSTRACT

UL

NSN 7540-01-280-5500

Standard Form 298 (Rev. 2-89) Prescribed by ANSI Std. Z39-18 